\title{
Social value cocreation: a mode of value cocreation
}

\author{
Michaela Haase
}

Marketing-Department, Freie Universität Berlin, Berlin, Germany

\author{
Abstract \\ Purpose - This paper aims to present a value cocreation framework that furthers understanding of social \\ value cocreation.
}

Design/methodology/approach - This paper is an interdisciplinary conceptual analysis drawing on social enterprise studies, marketing research and philosophical value theory. It applies a visible-hand approach to the study of market relationships and, in line with philosophical research strategies, unfolds its analysis using conceptual distinctions.

Findings - This study provides a framework that substantiates the distinction between two modes of value cocreation and identifies the structure of the social enterprise business model. It explains how social enterprises can be conceived as role models for for-profit organizations, and it elucidates why social value cocreation is a demanding objective.

Research limitations/implications - This paper develops an integrative, nondichotomist view of value cocreation that does not conceptualize social and economic value cocreation as opposing goals.

Practical implications - Social enterprises can use the business model structure and two modes of value cocreation and view themselves as role models for for-profit organizations.

Social implications - This paper applies a visible-hand approach to both for-profit organizations and social enterprises. Using its framework, for-profit organizations can reflect on the consequences of their actions on society and how social value cocreation can improve social enterprise effectiveness.

Originality/value - To the best of the author's knowledge, this paper is the first to bridge service-oriented approaches to marketing and social enterprise studies using philosophical value theory to improve understanding of social value cocreation.

Keywords Axiology, Business model, Social value, Economic value, Benefit/beneficiary, Visible hands

Paper type Research paper

\section{Introduction}

Value and value (co)creation have attracted attention in the marketing research and public management literature streams and in social enterprise studies. Using conceptualizations of value and value (co)creation that originate in service-oriented approaches to marketing studies, this paper explicates the basic structure of the social enterprise business model. The paper distinguishes the social enterprise organization from the social entrepreneur, ascribing to both the social enterprise organization (for brevity, hereinafter the paper skips the term

(C) Michaela Haase. Published by Emerald Publishing Limited. This article is published under the Creative Commons Attribution (CC BY 4.0) licence. Anyone may reproduce, distribute, translate and create derivative works of this article (for both commercial and non-commercial purposes), subject to full attribution to the original publication and authors. The full terms of this licence may be seen at http://creativecommons.org/licences/by/4.0/legalcode

The researcher gratefully acknoweldges the funding of her research by the German Research Foundation (DFG).
Received 22 April 2020 Revised 25 August 2020 13 October 2020 Accepted 21 October 2020

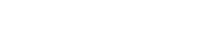


SEJ

17,4

"organization") and the social entrepreneur (as well as other members of the organization) objectives and activities addressed in terms of value cocreation. In line with criticisms of dichotomic views on the economic/social mission and on economics/ethics (Lautermann, 2013), the concept of value cocreation allows dealing with social enterprises and for-profit organizations within one analytical framework, addressing differences as modes of value cocreation. The paper explores the specificities of social enterprise in terms of social value cocreation and benefit creation - a difference between social value cocreation and benefit creation that requires attention in management and entrepreneurship education. Compared with the social enterprise and public management research streams, marketing studies have the longest tradition in the study of value (co)creation. Indeed, the service[1] -oriented approaches to marketing have moved value and value (co)creation to the center of their research interest. "Cocreation" relates to the idea of mutually connected actors who directly (in dyadic interactions) or indirectly (if the network or ecosystem is the level of analysis) cooperate to integrate resources and bring about those resource combinations they consider instrumental for their own performance or the change they aim to achieve. "Value creation" designates the valuation or appreciation (Meynhardt, 2009) of these resources or resource combinations conducted throughout the use processes in which resources are involved (Macdonald et al., 2011).

Although some research streams [e.g. the public management literature addressing public value (Kelly et al., 2002; Moore, 1995; Talbot, 2009), Seymour's (2012, p. 5) list of types of values (social value, cultural value, ecological value, spiritual value and creative value)] imply that many types of value exist, marketing studies tend to view value as a single concept rather than consider specifications of it, such as social and economic value [2].

Although value (co)creation is a major topic in marketing studies, value is underresearched and less understood (Eggert et al., 2019; Sánchez-Fernández and Iniesta-Bonillo, 2007). This applies to social enterprise studies as well, the attention given to social value creation notwithstanding (Haugh et al., 2018; Hlady-Rispal and Servantie, 2018). Both research fields would benefit from a better understanding of the influence objective, and subjective economic value theories have gained on conceptualizations of aspects of value in their respective research fields and the integration of philosophical value categories into their frameworks. Lautermann (2013, p. 184), pointing to the "fuzzy use of the attribute "social" in social entrepreneurship, has called for research to reveal its normative core. Similarly, to further study consumer value, Holbrook (1999) noted a need for philosophical value theory (axiology) that classifies "what things are good, and how good they are" (Schroeder, 2016, n.p.). Axiology has pointed out that the value problem is not a specifically ethical one (Krijnen, 2006). Holbrook (1999) proposed a typology that includes eight logically distinct types of value: efficiency, excellence, play, aesthetics, status, esteem, ethics and spirituality. As his typology indicates, values originate from not only value theory but also, for example, economics (efficiency and effectiveness), management (quality and performance) and sociology (relationship-related values).

This paper addresses the identified research gap, the underdetermination of the value concept, by unfolding two lines of argumentation. First, with reference to philosophical value theory (Hurka, 2006; Krijnen, 2006; Schmidt and Schischkoff, 1965), it argues that many studies deal with indicators of value rather than value. Thus, measures (profit or financial sustainability) are equated with economic value, but they are not value per se. Second, this paper investigates social value cocreation through the lens of the value cocreation framework originating from marketing studies. Based on the distinctions between economic and social mission (Chandra, 2019), value and benefit (Löbler, 2017; Haase, 2020a) and the private and the public realms (Arendt, 1958; Hussain, 2018), the paper identifies two modes of value cocreation that specify areas of activities for social enterprises 
and underlie the structure of their business models. As the meaning of the concept "business model" ranges from a system of ideas that gives orientation to organizational activities and processes related to value cocreation to a representation of concrete interconnected activities or processes devoted to value cocreation, this paper uses a broad understanding of the concept of business model - and one based on service logic (Karpen et al., 2012).

The service-oriented approaches to marketing studies, primarily the service-dominant (S-D) logic (Lusch and Vargo, 2014; Vargo and Lusch, 2004, 2017 [3]), have substituted the "creatingvalue-for" view formerly widely held by the marketing mainstream (i.e. the marketing concept [Houston, 1986]) for the "creating-value-with" view (Blocker and Barrios, 2015; Chandra, 2019; Eggert et al., 2019; Haase, 2015). Taking this perspective excludes the notion that value can be provided, transferred, captured or shared. To analyze value-oriented human or organizational performance (Arnould, 2014; Krijnen, 2006), this paper applies a value cocreation framework rather than the failure framework, according to which the activities of social enterprises or state authorities have their origin in market or government failure (Santos, 2012). Proponents of the failure approach do not highlight "human and societal flourishing" (Lautermann, 2013, p. 199), as do proponents of the value cocreation framework; rather, they posit that social enterprises solve problems that are in the world because markets or governments have caused them or failed to solve them. The failure framework provides only "a limited understanding of the functioning and formation of the markets" (Sigala, 2019, p. 28); it limits the role of the social enterprise/state to that of a repair shop/creator of public goods. In contrast, the public value discourse has overcome "the narrow market versus government failure approaches" (O'Flynn, 2007, p. 353), pointing out that public value is a different category than "traditional public goods" (Bennington, 2009, p. 236). Rejecting the failure approach, however, does not mean neglecting that social enterprises (Haugh et al., 2018) or public service organizations (Eriksson et al., 2020) are engaged in problem-solving.

The comprehensive EMES [4] approach of social enterprise (Defourny and Nyssens, 2014; Defourny and Nyssens, 2006; Borzaga and Defourny, 2001) mirrors the multidimensionality of the field of study delineated by social enterprise concepts: it blends entrepreneurship and innovation; the social economy, the third sector and the nonprofit sector; and business ethics, citizenship and sustainability (Bakaret and Grant, 2010; Mair et al., 2006). From the various economic, entrepreneurial and societal dimensions of the concept of social enterprise that Defourny and Nyssens (2006, p. 5f) and Mair et al. (2006) list, this paper draws on the two elements considered most characteristic for the social enterprise: first, the aim to benefit the community, to pursue a social mission or to exhibit a "common-good orientation" (Searing, 2014; Mair et al., 2012; Yockey, 2014; see Santos, 2012 for further references); second, the operation on markets or the conduct of resource transfers via markets (Bechetti and Borzaga, 2010). Social entrepreneurship adds innovation to these two elements (Nicholls, 2011).

Social enterprises are market-facing entities that gain access to the resources they need for their performance from other actors that cocreate value with them, including market actors. Market actors interact with social enterprises for both altruistic motives and the private benefits they expect to achieve from this relationship. Although they may accept that they pay a price higher than that they would be willing to pay to a for-profit enterprise, they nevertheless expect to achieve a private benefit from the interaction. Social enterprises stand, so to speak, with one leg in the regular market economy and must play, at least to some degree, according to its rules. With the other leg, social enterprises stand in the field of the social economy (in company with various other organizations or groups; see Haugh and Kitson, 2007). Social enterprises are advised not to underestimate the part that cocreation of private value plays in the pursuit of their social mission. That said, this does not imply that financial sustainability can be put on a par with the social mission. 
SEJ

17,4

The paper begins with a brief introduction to philosophical value theory and the S-D logic's views on value creation and value cocreation. Section 2 distinguishes indicators of social and economic value from value. Then, related to the two main constituents of the definition of the social enterprise concept, structural elements in the business model of social enterprises are identified, according to which, social enterprises have two options with regard to value cocreation. The paper ends with conclusions and suggestions for future research.

\section{Philosophical value theory}

Although value philosophy is as old as philosophy itself, Rudolf Hermann Lotze (18171881), one of the most influential German philosophers in the 19th century, introduced the concepts of value and validity (Geltung) into philosophy (Milkov, n.d.; Oldemeyer, 1980; Schmidt and Schischkoff, 1965). Lotze influenced more or less all philosophical schools in the late 19th and early 20th centuries, including phenomenology (Husserl), neo-Kantianism (Windelband, Rickert), pragmatism (James), Frege's logic, Dilthey's philosophy of life and analytical philosophy (Gabriel, 1989; Heinemann, 2019; Milkov, 2017, 2021). Following discussions in marketing studies (Eggert et al., 2019), social enterprise studies (Dees, 2011; Kokko, 2018; Santos, 2012) and public management studies (Eriksson et al., 2020; Kelly et al., 2002; Talbot, 2009), philosophical value theory highlights the value determinateness of human and organizational performance (Arnould, 2014; Krijnen, 2006; Lautermann, 2013). The philosophical value theory's perspective on the value creation debate in the aforementioned fields of study highlights that value does not emerge from activities, processes or things belonging to the "world of facts" (Lotze, 1885, p. 337); rather, it results from a human activity that links the "world of facts" and the "world of worth" (Lotze, 1885 [5], p. 337).

Lotze's distinction sheds light on value creation in two respects. First, it establishes the point of view of philosophy, that is, that value is a precondition of the "valueness" of an entity, not an inherent property of it. Values give orientation to human performance (as shared and empirically substantiated by psychologists, sociologists and anthropologists; see, e.g. Schwartz, 1992, 1994); they are something toward which one must have a stance. Philosophical value theory distinguishes between positive/negative (Unwert or Misswert), relative/absolute and subjective/objective values on the one hand (formal distinctions; Schmidt and Schischkoff, 1965) and logical, ethical and aesthetic values on the other hand (material distinctions; Schmidt and Schischkoff, 1965).

Second, Lotze's distinctions are a starting point for the work on valuations in terms of meaning and interpretation (Shapiro, 1993). The distinction between the world of facts and the world of worth is an analytical tool. The association of entities included in the world of facts (being constructs) with values included in the world of worth changes being constructs into meaning constructs (Krijnen, 2006). In social reality, individuals do not encounter pure facts (e.g. "meaningless needs"). Resources, which are integrated into resource use processes and thus transformed into a new type of resource (or resource combination), are meaning constructs. Individuals instantiate (validate) values through acts of valuation, a process that can be affected by human beings' consciousness, emotions and experiences but is not limited to factors "inside the mind" (Lamont, 2012, p. 205). In the context of propositions, valuation leads to decisions concerning their truth value: "The reality of a proposition means that it holds and that the opposite does not hold" (Lotze, 1887, p. 208). In parallel with propositions, which hold or do not hold (i.e. are true or not true), meaning constructs are characterized through values. Depending on the valuators' valuations, meaning constructs are thus 
beautiful or not beautiful, good or not good and so on. Value creation is the creation of meaning constructs, and valuation determines the validity of particular values.

Viewed through the lens of philosophical value theory, values are not experiences. Holbrook (1999, p. 8; emphasis in original), in his introduction to a volume on consumer value, provides an example for such a view, emphasizing that "consumer value resides not in the product purchased, not in the brand chosen, not in the object possessed but rather in the consumption experience(s) derived therefrom." With reference to Morris (1941), Holbrook (1999, p. 9; emphasis in original) continues, "the argument . . . boils down to the proposition that all products provide services in their capacity to create need- or want-satisfying experiences (Morris, 1941, p. 136). In this sense, all marketing is 'services marketing'." Holbrook correctly refers to services marketing that attends to the experiences that consumers can have throughout resource use processes. However, Holbrook equates the experiences had throughout a resource use process with value. In contrast, philosophical value theory maintains the view that values do not result from the world of facts, which includes human needs; in other words, "the simple subjectivation or anthropologization of value determination is unsatisfactory" (Krijnen, 2006, p. 549; my translation). Krijnen invites us to bear in mind nonhuman perspectives and unconditioned, objective values (Langton, 2007).

\section{Service-dominant lens on value creation and value cocreation}

According to the marketing concept, which remains the dominant view in marketing studies, organizations or firms transform resources into other resources and, in so doing, add value to them. Value is thus regarded as an objective attribute of an entity (good) brought about by an organization or firm; together with the respective entity, value is transferred to consumers at the point of sale; and consumers express via their demand (willingness to pay) whether they expect that the good's attributes will be valuable. In contrast to this "creating-value-for" view, the service-oriented approaches advocate the "creating-value-with" view, according to which individuals or organizations cannot create value for other individuals or organizations: on the one hand, value creation presumes value cocreation, but on the other hand, it presumes valuations.

Value creation and value cocreation are different constructs; in particular, value cocreation is not value creation conducted in cooperation (Haase, 2020b). Value cocreation rejects the view that firms (and other entities) can create value for another party. Rather, "cocreation" applies to concrete interactions within dyads such as those addressed in the German conceptualizations of customer integration (Kleinaltenkamp and Jacob, 2002) or other service-oriented approaches (Grönroos, 2011); it is also a characteristic of service networks (Löbler, 2013) or service ecosystems (Vargo et al., 2017; Vargo et al., 2008). By extending the dyadic perspective to a systems perspective, Webster and Lusch (2013, p. 394) point out that value is "co-created by all participants in the system (buyers, sellers, supply chain partners, government, etc.)." The meaning of "value cocreation" extends that of "division of labor." In Webster and Lusch's (2013, p. 394) view, "co-creation" stands for the control, the action opportunities, and the responsibility of all participants in the system as well. Sigala (2019, p. 31) connects social value cocreation with "learning with the market" or market actors' development of the capabilities necessary to cope with network structures, market practices, and "actors' understanding and interpretation of the market."

The S-D logic challenges the opposition of the economic and social realms, arguing that service exchange is not limited to the economy; rather, it is something that the economy and the society have in common (Lusch et al., 2016) [6]. From a service perspective, the economy is embedded in society, as all humans exchange service and are both service providers and

Social value cocreation 
service beneficiaries (Lusch and Vargo, 2014). In the social realm, service exchange encompasses both the social and the economic spheres; and both value creation and value cocreation exemplify the embeddedness of the economic sphere in the social sphere. That "value creation is inevitably social" (Helkkula et al., 2019, p. 126) and "value cocreation" is used to grasp the "full extent of interconnectedness with other actors" (Frow and Payne, 2019, p. 82) does not mean, however, that no difference exists between economic and social value.

Value creation takes place through the conduct of valuations throughout resource use processes, and such valuations give rise to value-in-use. The S-D logic refers to Aristotle's distinction between value-in-use and value-in-exchange, putting emphasis on the former. S-D logic's emphasis on value-in-use has furthered the study of use processes in marketing studies and, with it, the interest in learning how the user (customer) actually uses a resource (Macdonald et al., 2011). Until that point, the marketing and management literatures, focusing on value in exchange, were largely uninterested in what happens after the point of sale. However, as perspective has changed toward S-D logic, value-in-use has become a key concept in marketing, social enterprise and management studies (Hlady-Rispal and Servantie, 2018).

Marketing studies have discussed value in light of various determinants, including experience, pleasure and pain calculi, cost-benefit comparisons (Karababa and Kjeldgard, 2013; Sánchez-Fernández and Iniesta-Bonillo, 2007) and change (Becker, 2018; Blocker and Barrios, 2015). The S-D logic defines "value" as "an emergent, positively or negatively valued change in the well-being or viability of a particular system/actor" (Glossar_b, 2019, p. 740). S-D logic also highlights the interpretive and subjective bases of assessments (Vargo and Lusch, 2008). In line with this view, Meynhardt et al. (2016, p. 2983; emphasis in original) explain that "through the act of valuation (i.e. evaluation)" value - a meaning construct [7] "comes into being as an emergent phenomenon." Note that even though the term "value" designates the result of valuations, this does not exclude that negative value expressions can result from valuations (Echeverri and Skålén, 2011).

As consumer culture theory scholars (Arnould and Thompson, 2005) have emphasized, value is both a social and contextual phenomenon [for this reason, Vargo and Lusch (2008, p. 3) call consumer culture theory and S-D logic "natural allies"]. As valuation processes occur within particular relationships and social contexts, subjective values, shared among groups of individuals, and shared understandings exert influence on them: "Desires, needs, and evaluative efforts are not independent from the service ecosystem in which they occur" (Meynhardt et al., 2016, p. 2983).

Cocreation requires the development of shared understandings of what is potentially valuable for the beneficiaries involved in the exchange of service for service. In line with this, Ind and Coates (2013, p. 87) argue that cocreation "is not simply about the creation of things, it is also about interpretation and meaning making." Thus, the concept of value cocreation highlights the meanings related to interactions at all levels of analysis, or that people and organizations together generate and develop meaning through a participative process (Ind and Coates, 2013).

\section{Indicators of social and economic value}

The distinction between economic and social value assumes that activities and values are separable into economic and social ones. In this light, social value belongs to a family of concepts indicative of the social mission and economic value to a family of concepts used to designate economic objectives/achievements. However, this assumption makes questionable presuppositions, including that there are entities (goods) or activities (services) that embody 
or bring about one or the other kind of value; and value (singular) is often confused with the values (plural) that guide or influence why, how and with whom actors might be interested in engaging in value cocreation (Chandra, 2019; Haase, 2015).

Meynhardt et al. (2016, p. 2981) establish that "value is inherently and implicitly present in any study that investigates satisfaction, profit, or firm performance." In other words, such concepts as profit and satisfaction are not value but indicators of value. Table 1 presents a list of indicators originating from the literatures on social enterprise, management and marketing, showing the variety of topics addressed in terms of value.

The variability in how marketing studies discuss value, value creation and value cocreation shows the myriad ways value is understood and has given rise to the view that value is both a central concept (Blocker and Barrios, 2015; Eggert et al., 2019; Lindgreen, 2012) and "one of the most controversial issues" (Pongsakornrungsilp and Schroeder, 2011, p. 305). The confusion concerning value has an effect on the understanding of the distinctions between social and economic value, as well as between value and indicators of value. For instance, according to the marketing concept, a firm's major marketing objective is the satisfaction of consumer needs. However, although studies view the origin of economic value as the fulfillment of needs (Dixon, 1990), neither the needs nor their fulfillment are value.

The various interpretations of social and economic value in other fields of inquiry, including social enterprise studies, are problematic as well. Borzaga and Tortia (2010) subsume needs, a classical topos of consumer theory, under the heading "social value." Separating needs from the economic sphere is as questionable as extending human needs to social needs (Seeley, 1992). Common good, quality of life and social wealth are important topoi that themselves need clarification. The variety in the meaning of the term "social" (Cho, 2006; Seymour, 2012), the need to balance tensions between financial and social goals (Bechetti and Borzaga, 2010) and dichotomous understandings of the social and the economic (Lautermann, 2013; Osorio-Vega, 2019) are specific challenges for social enterprise studies.
Indicators of economic value

- Economic achievement (Osorio-Vega, 2019)

- Financial wealth (Zahra and Wright, 2016)

- Functional value

(Pongsakornrungsilp and Schroeder, 2011)

- Material value (Chell, 2007)

- Personal wealth (Chell, 2007; Zahra and Wright, 2016)

- Providing market segments with goods or services and thus with economic value (Corbett, 2016)

- Satisfaction, profit or firm performance (Trevelyan and Williams, 2019)

- Price/earnings ratios; the price ("the economic value of the exchange")

(Young, 2006)
Social value cocreation

499 2014)

- Positive societal transformation (Mongelli et al., 2019)

- Social impact assessment is based on "economic language and disciplined metrics-based thinking from the banking and finance sectors" (Cooney and Lynch-Cerullo, 2014)

Table 1. Indicators of value 
Krijnen (2006), using the term "value sphere," mentions four value categories: the practical realm, beauty, the sacred realm, and cognition. In light of the multiplicity of indicators of value and considering the origin of these indicators in scholarly theories and everyday knowledge, it is clear that the value categories established by axiology to date are in need of extension. Economic and marketing theories have established values or principles (e.g. efficiency, effectiveness) that provide orientation for the practices of many, if not most, forprofit organizations, and these theories have influenced nonprofit organizations as well. Holbrook's (1999) volume on consumer value translates efficiency into the ratio of outputs/ inputs and convenience. The service-oriented approaches, referring to Drucker (1958), established effectiveness as an economic principle or value (additional to efficiency). In comparison, social enterprise studies have no specified set of social values or principles. That said, groups of values, headed by "economic," "social" and other words, have found their way into the knowledge and belief systems of the actors in the life-world (Schutz, 1962). With regard to economic values, academic education may have played a role in the process of establishing their centrality. Porter (1985, p. 38), for example, established the mainstream view on economic value in marketing studies, stating that:

[...] value is the amount buyers are willing to pay for what a firm provides them. Value is measured by total revenue, a reflection of the price a firm's product commands and the units it can sell.

In sum, what distinguishes value categories from one another and how values are ranked depends on context and history and, thus, is subject to change. There is no economic value category independent from the development of value theories in economics and beyond. Scholarly theories inform actors about what can or should be considered valuable. Value creation, however, does not proceed on scholarly proposals, at least not without adaptations to life-world interpretations. The study of value propositions would be quite superfluous otherwise.

Until recently, the market and government failure lens established a need for social enterprises as repair shops. The value cocreation framework sheds a different light on the objectives and activities of social enterprises.

\section{Modes of value cocreation}

Distinctions and dichotomies such as those between the private and public sectors, the forprofit and nonprofit sectors, the economic and social realms and market and nonmarket relationships are fundamental to the understanding of the economy in many disciplines. This section introduces two important distinctions, which have consequences for a social enterprise's business model: the distinction between value and benefit and the distinction between private and nonprivate domains, institutions or entities. These two distinctions give rise to the structural peculiarity of the social enterprise business model.

\subsection{Value and benefit}

Regarding the first distinction, the analysis refers to Löbler's (2017) extension of service thought from the social realm to the natural realm. While the emergence of value presupposes valuations, service provision in the natural realm is restricted to the generation of benefit for the entities involved in service exchange (e.g. in symbiosis). In the social realm, the parties engaged in service exchange cocreate value. Value creation is valuation of entities (actors, resources, etc.), processes or activities (and their consequences) in the course of resource integration and service exchange. "Value cocreation" implies coengagement, 
coresponsibility and shared commitments and meanings, aiming at the benefit of the other party and one's own benefit.

However, as in the natural realm, the emergence of benefit does not presuppose value cocreation in the social realm. Benefit may arise from actions conducted without the beneficiary being aware of it or any concrete interactions between the beneficiary and the actor whose actions are the origin of the benefits in question. If, for example, a social enterprise manages to decrease the amount of food waste in a community, both the community and the ecosystem may benefit; however, neither the community nor the ecosystem may be aware of or appreciate such benefits.

S-D logic's definition of the concept of beneficiary presumes that the beneficiary and the valuator fall into one (Vargo et al., 2020). It stipulates that a beneficiary is "a focal actor that is experiencing value (positive or negative) in a particular context” (Glossar_a, 2019, p. 740). Building on the ideas embodied in the concepts "beneficiary" and "valuator," value cocreation requires achieving an understanding of what the beneficiary considers valuable or which resources the actors plan to integrate "to create their own experience" (Becker, 2018, p. 467) [8]. This definition, however, does not cover all cases of interest. Whereas value creation cannot occur without a valuing beneficiary, the emergence of benefit per se does not require such (Haase, 2020a; Löbler, 2017).

As all actions can have both intended and unintended consequences, all enterprises may unintentionally create benefits for other parties. That said, unintentional benefit creation is not a definitional attribute of social enterprises. Economics names unintended, positively assessed action consequences "positive externalities." This category does not apply to social enterprises; considering they are devoted to a social mission, they intentionally aim at the emergence of benefit for other entities. Conversely, social-welfare theory (Roth, 1999), which underlies the failure framework, does not require that individuals or organizations intentionally aim to create societal benefit or cocreate social value, respectively. Corbett's (2016, p. 608) remark that entrepreneurs "by their existence and action" do not per se "deliver positive value to society" does apply, highlighting the difference between a visible- and invisible-hand approach with regard to the actors' stance on aiming at value to society. According to the invisible-hand metaphor, a firm's business model targets the private sector only. If the assumptions of social-welfare theory are fulfilled, societal benefits accrue from the working of the invisible hand.

While abstract beneficiaries such as society, groups, or communities are unable to interact or engage themselves in cocreation and valuations, their representatives may be able to do so. This is a major theoretical precondition for social value cocreation to occur. A social entrepreneur who only assesses the benefits resulting from his or her activities for a societal entity but does not engage in the "co-creative practice of forming a value proposition" (Kowalkowski et al., 2012) targets the societal entity's benefit but does not cocreate social value. Social value cocreation requires the preparation of value propositions (i.e. "co-developed understandings of potential value"; Glossar_c, 2019, p. 740) by both parties. That benefits may emerge without value cocreation taking place between social enterprise and beneficiary does not mean, however, that they cannot be assessed - by the beneficiary itself, the social enterprise or third parties (e.g. scholars) assessing the benefits on their behalf. Table 2 summarizes the differences between value and benefit in light of the value cocreation framework.

\subsection{Two modes of value cocreation}

Drawing on the private/public distinction in political philosophy (Arendt, 1958; Hussain, 2018), this paper also distinguishes between private and nonprivate beneficiaries of
Social value cocreation 
SEJ

17,4

\section{2}

Table 2.

Value and benefit individual or organizational performance. The private beneficiary can be a family member, a household or a firm and, thus, an individual, a group or an organization. However, the mere existence of private beneficiaries of value cocreation does not imply a private society, that is, "a society whose members care only about their lives as private individuals" (Hussain, 2018, p. 3).

Table 3 combines the structural consequences of the value/benefit and private/ nonprivate distinctions for the social enterprise business model. As a market-facing entity, social enterprises engage in two modes of value cocreation in which private beneficiaries are always involved. The entries reflect the perspective of a social enterprise that is involved in interactions with private and nonprivate beneficiaries devoted to social value cocreation (Mode 1) or benefit creation (Mode 2). In light of the value cocreation framework, the for-profit organization is engaged in a mode of value cocreation less demanding than the social enterprise. Table 3 underscores that social value cocreation is an ambitious and challenging task. It requires, first, putting into action visible hands working for cocreating value with both private and nonprivate entities and, second, that the private and nonprivate beneficiaries conduct valuations either themselves or via an individual or group authorized by them. Recall that there is no value without valuation. A social enterprise that itself assesses the alleged benefits

Value Benefit

Service exchange and cocreation of value aiming at the Social enterprises/social entrepreneurs intentionally benefit of another entity and the entity itself Value creation $=$ valuation aim at creating benefit for another party. No service exchange but intended or unintended action consequence

Valuator $=$ beneficiary or a representative of the beneficiary
Private beneficiaries (individuals or organizations)
Nonprivate beneficiaries

(groups, communities, governmental agencies, social movements, nonprofit organizations, etc.)

\section{Mode 1}

Value Beneficiary = valuator Individuals conduct valuations on their own behalf (or on behalf of another private party) regarding diverse value categories; in marketing studies, the result is called "value" or, in case of an individual conducting valuations on behalf of a firm, "collective value"

Mode 2

Benefit Unintended benefits are possible

Table 3.

Structure of the social enterprise business model
Beneficiary = valuator:

Individuals or groups conduct valuations on behalf of a nonprivate party with reference to diverse value categories; the result is subsumed

under the term "social value"

\section{Beneficiary $\neq$ valuator}

This can mean that the beneficiary is either unable to conduct valuations itself or that there is no one available who does the valuations on its behalf. Parties other than the beneficiary assess the emergence of nonprivate benefits 
resulting from its performance may have contributed to the societal entity's benefit but has not cocreated social value with it.

To illustrate the distinctions exemplified by Table 3 with regard to social value cocreation, consider an imaginary example of a social enterprise (social enterprise*) selling nutritionally enriched food (bread) to low-income people in less-developed countries. Selling bread to improve the dietary quality of the population and to increase a society's levels of education or health requires considering both individual (private) and societal (nonprivate) beneficiaries. Social enterprise*'s business model assumes that improving children's nutrition and health can increase their success in school and, ceteris paribus, the level of education or health in the community to which the children belong. Accessing resources through market exchange means that social enterprise* "sells" the bread to private market actors in the hope that they make use of it in a way conforming to its business model. In other words, there is an exchange of resources between social enterprise* and its private beneficiaries, including time, information, nominal goods and physical entities (bread). In S-D terms, social enterprise* exchanges service (its ability to prepare nutritionally enhanced bread, embodied in the physical resource, the bread) for service (the customer's financial resources as well as ability and willingness to make adequate use of the bread).

The social mission can only be achieved if social enterprise* manages to share beliefs or interpretations about the meaning of its offering with its private and nonprivate cocreators of value. Simply "selling" bread does not ensure that children actually use it in the way social enterprise* $^{*}$ assumes (because of its low price, the resource might be used to feed, e.g. the family's cow). As the real-life example of relief goods exchanged shortly after having passed the point of distribution shows, the usability of resources and actual resource use processes are a topic of crucial interest for social enterprises. Kilian Kleinschmidt, who supervised one of the largest refugee camps (Zataa in Jordan), observed: "We distributed relief goods immediately exchanged by the refugees for money in order to buy what they really wanted" [9]. If the children actually use (consume) the resource, this would result in a better health condition, but there is no mechanism to ensure that they are able to attend school or are willing to perform well there. For this reason, the respective activities of the private beneficiaries must be considered resources that the local government agencies can integrate in public value cocreation. For the success of the social mission (i.e. the lifting of the society's level of education), social enterprise* must rely on the cooperation of both the private cocreators and the nonprivate entities. With social value cocreation, mutual value propositions or shared understandings concerning the cocreators' objectives and the suitability of the cocreators' activities for the achievement of these objectives are necessary. It is through their value propositions that both parties assure each other how they plan to make use of their skills and other resources. If the local authorities do not provide such things as school buildings and educated teachers, then social enterprise*'s business model fails. Note that this does not eradicate the benefits the private customers have gained and may further gain from the service exchange, but this is not the rule.

In light of Table 3, a major distinction between a social enterprise and a for-profit enterprise is that the business model of social enterprises explicitly includes nonprivate beneficiaries. If one disregards the ranking of beneficiaries (i.e. nonprivate over private for social enterprises and private over nonprivate for for-profits), this is, what can and should be expected from every responsibly acting for-profit organization. In this regard and to this extent, social enterprises are economic role models. Pursuing a social mission, however, extends the role-model criterion in two respects. First, social value cocreation/benefit creation is not an add-on to value cocreation with the private beneficiary; it is at the core of
Social value cocreation

503 
social enterprise. Second, social enterprises intentionally aim to benefit the nonprivate beneficiary or to cocreate social value with him/her; hence, they need to know what benefits the respective nonprivate beneficiary considers valuable.

\subsection{Value, values and indicators of value}

Social value cocreation takes from the shoulders of the social enterprise the burden to determine what the societal entity considers valuable. In contrast, targeting societal benefit puts the burden of responsibility for actions and action consequences on the social enterprise, drawing on its values, resources and legitimization. Nevertheless, from an ethical or axiological perspective it is expected of all actors that they orientate their performance to axiological values (which include ethical but not, e.g. economic or management values).

The distinction between private and nonprivate beneficiaries does not concur with that between creators of economic and social value (Lautermann, 2013). Both private and nonprivate beneficiaries, insofar as they engage in valuations, can refer to all value categories, irrespective of their origin from or assignment to philosophy or social science. Indicators of economic value are present in many discourses related to social enterprise, marketing and management studies (Table 1); they provide orientation to all types of actors and organizations, market and nonmarket, for-profit and nonprofit, private and nonprivate, etc. The point here is that they are not suited to determine content and purpose of human and organizational performance. The value cocreation framework may ultimately be as helpful for modifying the prevailing understanding of economic action based on neoclassical economics. As the service-oriented approaches to marketing studies have not yet given sufficient attention to the full range of value categories, the social enterprises, because of the indicators of social value they refer to, may work as catalysts in that they show how values give orientation to human or organizational action.

\subsection{Social enterprises as market-facing entities}

As market-facing entities, social enterprises should not neglect the role of cocreating private value in pursuing their social mission. The many people "locked into narrow traditional business thinking" (Osorio-Vega, 2019, p. 983) notwithstanding, the private beneficiary is an important actor in the value cocreation framework. Social enterprises prepare market offerings for which they must find customers who are willing to integrate them into their resource use processes. It is assumed that actors are willing to do so, if they expect that the result of the valuation of the respective potential resources is positive.

From a dualistic perspective on the market and the state, social enterprises have faced skepticism concerning the consistency of their activities and their overall sustainability (Bechetti and Borzaga, 2010). As "organizations that pursue social and economic missions" (Chandra, 2019, p. 237), social enterprises' market-facing activities devoted to the creation of private benefits are often regarded as hampering the social mission or giving rise to mission drift. Bechetti and Borzaga (2010, p. 10) argue that "the tensions between the financial and social goals will inevitably make social enterprises unsustainable." The current study's analysis demonstrates that the word "inevitably" is misleading: the invisible-hand metaphor mirrors dichotomies and distinctions, which are prevalent in contemporary academic disciplines or fields of study, rather than fundamental differences in the "value cocreation logics" between social enterprises and for-profit organizations. The current paper's analysis, however, has shed light on dual mission complexity (Doherty et al., 2014).

This paper uses the words "dual mission" and "economic mission" and emphasizes the importance of cocreation of private value and thus acknowledges the role market-based access to financial resources plays for social enterprises; however, it does not go so far as to 
place the financial and the social foci into opposition. Within the value cocreation framework, financial resources constitute one resource among many others, and the success or survival of the social enterprise, as of any organization, depends on all the resources it needs for its performance. Thus, "financial sustainability" does not equate to "economic mission" and is not considered at the same level as the social mission.

The economic dimensions of the social enterprise's agenda do not have a negative effect on the social mission per se. Quite the contrary, understanding the economic mission in terms of value cocreation and the role it plays for the achievement of the social mission in terms of resource transfer is an important precondition for the social mission's success. This does not mean that the relation between the two objectives (missions) is without conflict. The literature on hybrid organizations has provided ample evidence of this (Castellas et al., 2019; Doherty et al., 2014). Even if they are clearly ranked, subordinated managerial decisions between conflicting alternatives may be necessary, including different answers to the question of what benefits whom in the service network or is in the public interest (Cho, 2006). However, tensions and conflicts are conceivable as parts of the social world, not as a threat to it.

\section{Conclusions and outlook}

The paper expands the understanding of value cocreation in three respects. First, drawing from the marketing and social enterprise literatures, it provides a common value cocreation framework for the study of social enterprises and for-profit organizations. Second, it identifies two modes of value cocreation with regard to social enterprises, that is, Mode 1, the social enterprise's cocreation of value with private/nonprivate beneficiaries (social value cocreation) and, Mode 2, the social enterprise's cocreation of value with private beneficiaries in favor of nonprivate beneficiaries (benefit creation). Mode 1 includes value cocreation with both private and nonprivate beneficiaries; Mode 2 includes value cocreation with the private beneficiary only. One enterprise can be simultaneously engaged in both modes. Third, the paper distinguishes between value and indicators of value.

The indicators of value that private entities strive for are often equalized with profit or utility (an interpretation that harks back to neoclassical economics). The S-D logic opposes dichotomic understandings of the social and the economic, arguing that "the purpose of exchange is to mutually serve" (Vargo and Lusch, 2008, p. 5; emphasis in original). In light of this paper's analysis, indicators of value stand for meanings embodied in various scholarly theories that overflow into life-world discourses. As the S-D logic with regard to marketing studies and Table 1 with regard to social enterprise studies show, these meanings are under debate.

Whereas public management research and social enterprise studies address public value and social value, respectively, marketing studies view "value" as a generic term. This seems to be correct. Given the distinction between value and values, the problem here is not the generic concept of value but the nonaxiological type of value categories that marketing and social enterprise studies often prefer to use. Indicators of value are often only loosely coupled with specific value categories (e.g. "socio-effectiveness"; Hlady-Rispal and Servantie, 2018, p. 74) - an issue in need of further investigation. The same applies to valuation and valuation processes and the interplay of subjective and objective factors therein. On the one hand, valuation is inherently subjective, devoted to private value. On the other hand, the sources from which valuations can draw include objective, unconditioned values and knowledge. In addition, individuals or groups can engage in valuations on behalf of themselves or other parties, particularly nonprivate, societal entities. It should also be considered that valuations are not only done for society but also in society (Vatin, 2013; Lamont, 2012). 
From the concept of social value cocreation accrue a number of research questions, including the following:

Q1. How can and do societal entities such as communities or societies, or their respective representatives, determine what is potentially valuable?

Q2. What is the role of knowledge, argument, interest, power or negotiation in valuation processes?

Q3. How can value proposals gain legitimacy in the social enterprise organization and for its stakeholders?

Q4. How can and do potential beneficiaries of a social enterprise's performance (i.e. groups, communities or societies) conduct the valuations that are essential to the cocreation of social value?

Q5. How can and do the valuations draw from both axiological and nonaxiological value categories or indicators of value, respectively?

Social value cocreation is a mode of value cocreation that rests on the integration of the beneficiary's resources. Given the parties' willingness and ability to cooperate, and by drawing from the beneficiary's firsthand knowledge and shared value proposals, social value cocreation is expected to be more effective than benefit creation - "effective" in the sense of the phrase "bringing something about that the other party considers/the stakeholders consider valuable." Thus, neither the value cocreation framework nor the establishment of value propositions leads to uncontested conceptions of social value. Value cocreation, however, implies (some) agreement, some "shared conception" (De Bruin and Teasdale, 2019, p. 3) established among the parties involved in the preparation of value propositions. This is an agreement arrived at a certain point of time, in a certain context or situation (giving rise to value in context). The axiological good (of states of affairs) or the ethical rightness of actions intentions or action consequences must be carved out through intense confrontation with the aforementioned philosophical values. Objective, unconditioned values and values buttressed by scholarly knowledge may have the highest potential to be "uncontroversial or transportable across contexts" (Lamont, 2012, p. 206).

Given the number and variety of stakeholders, social enterprises may engage in both social value cocreation and benefit creation within the service network. Social entrepreneurs and social enterprise organizations that do not develop value propositions in cooperation with their respective nonprivate beneficiaries should draw on scholarly or network knowledge about "what has social value" (De Bruin and Teasdale, 2019, p. 3) to identify potential benefits or problem solutions and to avoid becoming restricted to internal logics and self-legitimizing discourses (Nicholls, 2011). Further research may also address the legitimacy of social enterprises' beneficial actions and their assessment in light of ethics and value theory (Beauchamp, 2019).

\section{Notes}

1. The word "service" has two meanings. First, "service" pertains to services (plural) or offerings that can be distinguished from goods by the so-called IHIP paradigm [intangibility, heterogeneity, inseparability and perishability; Benoit (née Moeller), 2010]. With the IHIP paradigm, service-oriented approaches reject the characterization of services by attributes, which are the opposite of what characterizes goods, thus creating a dichotomy between services and goods. Second, "service" (singular) is defined as "the application of specialized competences 
(knowledge and skills) through deeds, processes, and performances for the benefit of another entity or the entity itself" (Vargo and Lusch, 2004, p. 2). This paper refers to service (singular). For an overview of conceptualizations of otherness in social theory, refer to Palacios (2009, Chapter 1).

2. According to the American Marketing Association's most recent definition of "marketing" issued in 2013, it is "the activity, set of institutions, and processes for creating, communicating, delivering, and exchanging offerings that have value for customers, partners, clients, and society at large" (emphasis added). www.ama.org/the-definition-of-marketing/

3. For assessments of the S-D logic's development and achievements, refer to Kryvinska et al. (2013) and Vargo and Lusch (2017).

4. "EMES" stands for "EMergence des Entreprises Sociales en Europe." The EMES research network originated from a research project carried out between 1996 and 2000. As a result of this project, Defourny and Nyssens (2014) present three sets of criteria for identifying social enterprises: economic and entrepreneurial dimensions, social dimensions and participatory governance.

5. Lotze's Mikrokosmos, published in 1856, 1858 and 1864, was translated from German into English and published in two volumes in 1885.

6. Löbler (2017) has further extended this view, integrating human-nature and nature-nature interactions. This paper only addresses service provision in the social realm or human-human interactions.

7. The world of facts is an analytical tool. All phenomena of social-scientific analysis are meaning constructs.

8. Recall that creating experience is not tantamount to creating value.

9. "Wir haben Hilfsmittel verteilt, die haben die Flüchtlinge sofort weiter verteilt, um Bargeld zu bekommen und sich zu kaufen, was sie wirklich wollen." Süddeutsche Zeitung, No. 218, September 20, 2019, p. 26.

\section{References}

Achleitner, A.-K. (2016), "Social entrepreneurship”, Springer Gabler Verlag, Gabler Wirtschaftslexikon, available at: http://wirtschaftslexikon.gabler.de/Archiv/152065/social-entrepreneurship-v5.html (accessed 2 September 2019).

Arendt, H. (1958), The Human Condition, University of Chicago Press, Chicago.

Arnould, E.J. (2014), "Rudiments of value praxeology", Marketing Theory, Vol. 14 No. 1, pp. 129-133.

Arnould, E.J. and Thompson, C.J. (2005), "Consumer culture theory (CCT): twenty years of research", Journal of Consumer Research, Vol. 31 No. 4, pp. 868-882.

Bakaret, J. and Grant, S. (2010), "Editorial”, Third Sector Review, Vol. 16, pp. 2-9.

Beauchamp, T. (2019), "The principle of beneficience in applied ethics", available at: https://plato. stanford.edu/archives/spr2019/entries/principle-beneficence/ (accessed 13 October 2020).

Bechetti, L. and Borzaga, C. (2010), "Introduction”, in Bechetti, L. and Borzaga, C. (Eds), The Economics of Social Responsibility, Routledge, Milton Park, UK, and New York, NY, pp.1-14.

Becker, L. (2018), "Methodological proposals for the study of consumer experience", Qualitative Market Research: An International Journal, Vol. 21 No. 4, pp. 465-490.

Bennington, J. (2009), “Creating the public in order to create public value?", International Journal of Public Administration, Vol. 32 Nos 3/4, pp. 232-249.

Benoit (née Moeller), S. (2010), "Characteristics of services - a new approach uncovers their value", Journal of Services Marketing, Vol. 24 No. 5, pp. 359-368. 
Blocker, C.P. and Barrios, A. (2015), "The transformative value of a service experience", Journal of Service Research, Vol. 18 No. 3, pp. 265-283.

Borzaga, C. and Defourny, J. (Eds), (2001), The Emergence of Social Enterprise, Routledge, London.

Borzaga, C. and Tortia, E. (2010), "The competitive advantages of social enterprises", in Bechetti, L. and Borzaga, C. (Eds) The Economics of Social Responsibility, Routledge, Milton Park, UK and New York, NY, pp. 15-33.

Castellas, E.I., Stubbs, W. and Ambrosini, V. (2019), "Responding to value pluralism in hybrid organizations”, Journal of Business Ethics, Vol. 159 No. 3, pp. 635-650.

Chandra, Y. (2019), "Whose value? Problems in valuing social enterprise and research implications", Social Enterprise Journal, Vol. 15 No. 2, pp. 233-242.

Chell, E. (2007), "Social enterprise and entrepreneurship: towards a convergent theory of the entrepreneurial process", International Small Business Journal: Researching Entrepreneurship, Vol. 25 No. 1, pp. 5-23.

Cho, A.H. (2006), "Politics, values and social entrepreneurship: a critical appraisal", in Mair, J., Robinson, J. and Hockerts, K. (Eds), Social Entrepreneurship, Palgrave Macmillan, New York, NY, pp.34-56.

Cooney, K. and Lynch-Cerullo, K. (2014), "Measuring the social return of nonprofits and social enterprises: the promise and perils of the SROI", Nonprofit Policy Forum, Vol. 5 No. 2, pp. 367-393.

Corbett, A. (2016), "Social entrepreneurship as a norm?”, Journal of Management Studies, Vol. 53 No. 4, pp. 608-609.

De Bruin, A. and Teasdale, S. (2019), "Exploring the terrain of social entrepreneurship”, in De Bruin, A. and Teasdale, S. (Eds), A Research Agenda for Social Entrepreneurship, Edward Elgar, Cheltenham, UK, and Northampton, MA, pp.1-12.

Dees, J.G. (2011), “The meaning of social entrepreneurship”, in Hamschmidt, J. and Pierson, M. (Eds), Case Studies in Social Entrepreneurship and Sustainability. The Oikos Collection, Vol. 2. Routledge, London and New York, NY, pp.2-30.

Defourny, J. and Nyssens, M. (2006), "Defining social enterprise”, in Nyssens, M. (Ed.), Social Enterprise: At the Crossroads of Market, Public Policy and Civil Society, Routledge, London and New York, NY, pp.3-26.

Defourny, J. and Nyssens, M. (2014), "The EMES approach of social enterprise in a comparative perspective", in Defourny, J., Hulgård, L. and Pestoff, V. (Eds), Social Enterprise and the Third Sector: changing European Landscapes in a Comparative Perspective, Routledge, Milton Park et al. and New York, NY, pp. 42-65.

Dixon, D.F. (1990), "Marketing as production: the development of a concept", Journal of the Academy of Marketing Science, Vol. 18 No. 4, pp. 137-143.

Doherty, B., Haugh, H. and Lyon, F. (2014), "Social enterprises as hybrid organizations: a review and research agenda", International Journal of Management Reviews, Vol. 16 No. 4, pp. 417-436.

Drucker, P.F. (1958), "Marketing and economic development", Journal of Marketing, Vol. 22 No. 3, pp. 252-259.

Dufays, F. and Huybrechts, B. (2014), "Connecting the dots for social value: a review on social networks and social entrepreneurship”, Journal of Social Entrepreneurship, Vol. 5 No. 2, pp. 214-237.

Echeverri, P. and Skålén, P. (2011), "Co-creation and co-destruction: a practice-based study of interactive value formation", Marketing Theory, Vol. 11 No. 3, pp. 351-373.

Eggert, A., Kleinaltenkamp, M. and Kashyap, V. (2019), "Mapping value in business markets: an integrative framework", Industrial Marketing Management, Vol. 79 No. 5, pp. 13-20. 
Eriksson, E., Andersson, T., Hellström, A., Gadolin, C. and Lifvergren, S. (2020), "Collaborative public management: coordinated value propositions among public service organizations", Public Management Review, Vol. 22 No. 6, pp. 791-812.

Frow, P. and Payne, A. (2019), "Value cocreation: an ecosystem perspective", in Vargo, S.L. and Lusch, R.F. (Eds), The SAGE Handbook of Service-Dominant Logic, SAGE Publications, Thousand Oaks, CA, pp. 80-96.

Gabriel, G. (1989), "Einleitung des Herausgebers: Objektivität: Logik und Erkenntnistheorie bei Lotze und Frege", in Lotze, H. (Ed.), Logik. Drittes Buch. Vom Erkennen (Methodologie), Felix Meiner, Hamburg, pp. 9-27.

Glossar_a (2019), "Beneficiary", in Vargo, S.L. and Lusch, R.F. (Eds), The SAGE Handbook of ServiceDominant Logic, SAGE Publications, Thousand Oaks, CA, p. 740.

Glossar_b (2019), "Value", in Vargo, S.L. and Lusch, R.F. (Eds), The SAGE Handbook of ServiceDominant Logic, SAGE Publications, Thousand Oaks, CA, p. 740.

Glossar_c (2019), "Value proposition”, in Vargo, S.L. and Lusch, R.F. (Eds), The SAGE Handbook of Service-Dominant Logic, SAGE Publications, Thousand Oaks, CA, p.740.

Grönroos, C. (2011), "Value co-creation in service logic: a critical analysis", Marketing Theory, Vol. 11 No. 3, pp. 279-301.

Haase, M. (2015), "Values-based value creation and responsibility: on the relationship of 'doing business' and 'doing CSR”, Zeitschrift für Wirtschafts- und Unternehmensethik (zfwu), Vol. 16 No. 3, pp. 339-368.

Haase, M. (2020a), "The extension of service thought from the social realm to the realm of nature: an investigation giving focus to sustainability and salues", in Stieler, S. (Ed.), Marketing as a Social Science: Festschrift für Universitäts Professor Dr h.c. Helge Löbler, Books on Demand, Norderstedt, pp. 97-119.

Haase, M. (2020b), "Considering value-related concepts in service-oriented approaches to marketing studies in light of philosophical and economic value theories", Journal of Service Management Research, Special Issue Turning the Sounds of Service: Essays in Honour of Michael Kleinaltenkamp, Vol. 44 Nos 2/3, pp. 133-144.

Haugh, H. and Kitson, M. (2007), "The third way and the third sector: new labour's economic policy and the social economy", Cambridge Journal of Economics, Vol. 31 No. 6, pp. 973-994.

Haugh, H., Lyon, F., and Doherty, B. (2018), "Social entrepreneurship: entrepreneurship and social value creation", in Backburn, R., De Clercq, D. and Heinonen, J. (Eds), The SAGE Handbook of Small Business and Entrepreneurship, SAGE Publications, Thousand Oaks, CA, pp.125-142.

Heinemann, A.-S. (2019), "Frege und die kontinentalen Ursprünge der analytischen Philosophie", History and Philosophy of Logic, Vol. 40 No. 4, pp. 403-406.

Helkkula, A., Dube, A., and Arnould, E. (2019), "The contextual nature of value and value cocreation", in Vargo, S.L. and Lusch, R.F. (Eds), The SAGE Handbook of Service-Dominant Logic, SAGE Publications, Thousand Oaks, CA, pp.118-132.

Hlady-Rispal, M. and Servantie, V. (2018), "Deconstructing the way in which value is created in the context of social entrepreneurship", International Journal of Management Reviews, Vol. 20 No. 1, pp. $62-80$.

Holbrook, M.B. (1999), "Introduction to consumer value", in Holbrook, M.B. (Ed.), Consumer Value: A Framework for Analysis and Research, Routledge, London and New York, NY, pp.1-28.

Houston, F.S. (1986), "The marketing concept: what it is and what it is not", Journal of Marketing, Vol. 50 No. 2, pp. 81-87.

Hurka, T. (2006), "Value theory", in Copp, D. (Ed.), The Oxford Handbook of Ethical Theory, Oxford University Press, Oxford, pp.357-379.

Hussain, W. (2018), "Common good", Stanford Encyclopedia of Philosophy, available at: https:/plato. stanford.edu/entries/common-good/ (accessed 13 October 2020). 
Ind, N. and Coates, N. (2013), "The meanings of co-creation”, European Business Review, Vol. 25 No. 1, pp. 86-95.

Karababa, E. and Kjeldgard, D. (2013), "Value in marketing: toward socio-cultural perspectives", Marketing Theory, Vol. 14 No. 1, pp. 127-199.

Karpen, I.O., Bove, L.L. and Lukas, B.A. (2012), "Linking service-dominant logic and strategic business practice: a conceptual model of a service-dominant orientation”, Journal of Service Research, Vol. 15 No. 1, pp. 21-38.

Kelly, G., Mulgan, G. and Muers, S. (2002), “Creating public value: an analytical framework for public service reform", discussion paper, Cabinet Office Strategy Unit.

Kleinaltenkamp, M. and Jacob, F. (2002), "German approaches to business-to-business marketing theory: origins and structure", Journal of Business Research, Vol. 55 No. 2, pp. 149-155.

Kokko, S. (2018), "Social entrepreneurship: creating social value when bridging holes", Social Enterprise Journal, Vol. 14 No. 4, pp. 410-428.

Kowalkowski, C., Ridell, O.P., Röndell, J.G. and Sörhammar, D. (2012), "The co-creative practice of forming a value proposition”, Journal of Marketing Management, Vol. 28 Nos 13/14, pp. 1553-1570.

Krijnen, C. (2006), "Wert”, in Düwell, M., Hübenthal, C., and Werner, M. H. (Eds), Handbuch Ethik, J. B. Metzler, Stuttgart and Weimar, pp.548-553.

Kryvinska, N., Olexova, R., Dohmen, P. and Stauss, C. (2013), "The S-D logic phenomenon conceptualization and systematization by reviewing the literature of a decade (2004-2013)", Journal of Service Science Research, Vol. 5 No. 1, pp. 35-94.

Lamont, M. (2012), “Toward a comparative sociology of valuation and evaluation”, Annual Review of Sociology, Vol. 38 No. 1, pp. 201-221.

Langton, R. (2007), “Objective and unconditioned value”, Philosophical Review, Vol. 116 No. 2, pp. 157-185.

Lautermann, C. (2013), "The ambiguities of (social) value creation: towards an extended understanding of entrepreneurial value creation for society”, Social Enterprise Journal, Vol. 9 No. 2, pp. 184-202.

Lindgreen, A. (2012), "Value in business and industrial marketing", Industrial Marketing Management, Vol. 41 No. 1, pp. 4-7.

Löbler, H. (2013), "Service-dominant networks: an evolution from the service-dominant logic perspective", Journal of Service Management, Vol. 24 No. 4, pp. 420-434.

Löbler, H. (2017), "Humans' relationship to nature - framing sustainable marketing", Journal of Services Marketing, Vol. 31 No. 1, pp. 73-82.

Lotze, H. (1885), Microcosmos: An Essay Concerning Man and His Relation to the World, translated from the German by Elizabeth Hamilton and E.E. Constance Jones, in two volumes, T. \& T. Clark, Edinburgh.

Lotze, H. (1887), Logic in Three Books of Thought, of Investigation and of Knowledge, English translation, edited by Bernard Bosanquet, second edition in two volumes, Clarendon Press, Oxford.

Lusch, R.F. and Vargo, S.L. (2014), Service-Dominant Logic: Premises, Perspectives, Possibilities, Cambridge University Press, Cambridge.

Lusch, R.F., Vargo, S.L. and Gustafsson, A. (2016), "Fostering a trans-disciplinary perspectives of service-ecosystems", Journal of Business Research, Vol. 69 No. 8, pp. 2957-2963.

Macdonald, E.K., Wilson, H., Martinez, V. and Toossi, A. (2011), "Assessing value-in-use: a conceptual framework and exploratory study", Industrial Marketing Management, Vol. 40 No. 5, pp. 671-682.

Mair, J., Battilana, J. and Cardenas, J. (2012), "Organizing for society: a typology of social entrepreneurship models", Journal of Business Ethics, Vol. 111 No. 3, pp. 353-373.

Mair, J., Robinson, J., and Hockerts, K. (2006), "Introduction”, in Mair, J., Robinson, J. and Hockerts, K. (Eds), Social Entrepreneurship, Palgrave Macmillan, New York, NY, pp. 1-13. 
Meynhardt, T. (2009), "Public value inside: what is public value creation?", International Journal of Public Administration, Vol. 32 Nos 3/4, pp. 192-219.

Meynhardt, T., Chandler, J. and Strathoff, P. (2016), "Systemic principles of value co-creation: synergetics of value and service ecosystems", Journal of Business Research, Vol. 69 No. 8, pp. 2981-2989.

Milkov, N. (2017), "Einleitung: Hermann Lotzes philosophische Synthese", in Lotze, R.H. (Ed.), Mikrokosmos. Ideen zur Naturgeschichte und Geschichte der Menschheit. Versuch einer Anthropologie, Reprint of the 6th Edition, Felix Meiner, Hamburg, pp. 11-69.

Milkov, N. (2021), "Rudolf Hermann Lotze (1817-1881)”, in Internet Encyclopedia of Philosophy, available at: www.iep.utm.edu/lotze/ (accessed 13 October 2020).

Mongelli, L., Rullani, F., Ramus, T. and Rimac, T. (2019), "The bright side of hybridity: exploring how social enterprises manage and leverage their hybrid culture", Journal of Business Ethics, Vol. 159 No. 2, pp. 301-305.

Moore, M.H. (1995), Creating Public Value. Strategic Management in Government, Harvard University Press, Cambridge, MA.

Morris, R.T. (1941), The Theory of Consumer Demand, Yale University Press, New Haven, CT.

Nicholls, A. (2011), "Social enterprise and social entrepreneurs", in Edwards, M. (Ed.), The Oxford Handbook of Civil Society, Oxford University Press, Oxford, pp.80-92.

O'Flynn, J. (2007), "From new public management to public value: paradigm change and managerial implications", Australian Journal of Public Administration, Vol. 66 No. 3, pp. 353-366.

Oldemeyer, E. (1980), "Wert", in Speck, J. (Ed.), Handbuch wissenschaftstheoretischer Begriffe, Band 3, Vandenhoeck and Ruprecht, Göttingen, pp.701-702.

Osorio-Vega, P. (2019), "The ethics of entrepreneurial shared value”, Journal of Business Ethics, Vol. 157 No. 4, pp. 981-995.

Palacios, M. (2009), Fantasy and Political Violence: The Meaning of Anti-Communism in Chile, VS Verlag für Sozialwissenschaften | GWV Fachverlage GmbH, Wiesbaden.

Pongsakornrungsilp, S. and Schroeder, J.E. (2011), "Understanding value co-creation in a co-consuming brand community”, Marketing Theory, Vol. 11 No. 3, pp. 303-324.

Porter, M.E. (1985), Competitive Advantage: Creating and Sustaining Superior Performance, The Free Press, New York, NY.

Roth, T.P. (1999), Ethics, Economics and Freedom, Aldershot, Ashgate, UK, Singapore and Sydney.

Sánchez-Fernández, R. and Iniesta-Bonillo, M. Á (2007), "The concept of perceived value: a systematic review of the research", Marketing Theory, Vol. 7 No. 4, pp. 427-451.

Santos, F.M. (2012), "A positive theory of social entrepreneurship", Journal of Business Ethics, Vol. 111 No. 3, pp. 335-351.

Schmidt, H. and Schischkoff, G. (1965), Philosophisches Wörterbuch, 17 ed., Kröner, Stuttgart, Vol. 13.

Schroeder, M. (2016), "Value theory", The Stanford Encyclopedia of Philosophy (Fall 2016 Edition), Zalta, E. N. (Ed.), available at: https:/plato.stanford.edu/archives/fall2016/entries/value-theory/ (accessed 13 October 2020).

Schutz, A. (1962), "The problem of social reality. Collected papers I, edited and introduced by maurice natanson", Martinus Nijhoff, The Hague, Boston and London.

Schwartz, S.H. (1992), "Universals in the content and structure of values: theoretical advances and empirical tests in 20 countries", Advances in Experimental Social Psychology, Vol. 25, pp. 1-65.

Schwartz, S.H. (1994), "Are there universal aspects in the structure and contents of human values?", Journal of Social Issues, Vol. 50 No. 4, pp. 19-45.

Searing, E.A.M. (2014), "Judging a book by its cover: the role of corporate form in social enterprise startups", available at: http://ssrn.com/abstract=2534782 (accessed 13 October 2020$)$.

Social value cocreation

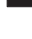


SEJ

17,4

Seeley, E. (1992), "Human needs and consumer economics: the implications of Maslow's theory of motivation for consumer expenditure patterns", The Journal of Socio-Economics, Vol. 21 No. 4, pp. 303-324.

Seymour, R.G. (2012), Handbook of Research Methods on Social Entrepreneurship, Edward Elgar, Cheltenham, UK, and Northampton.

Shapiro, M.J. (1993), Reading “Adam Smith”: Desire, History, and Value, SAGE, Newbury Park, CA, London and New Delhi.

Sigala, M. (2019), "A market approach to social value co-creation: findings and implications from 'Mageires' the social restaurant”, Marketing Theory, Vol. 19 No. 1, pp. $27-45$.

Talbot, C. (2009), "Public value-the next 'big thing' in public management?", International Journal of Public Administration, Vol. 32 Nos 3/4, pp. 167-170.

Trevelyan, J. and Williams, B. (2019), "Value creation in the engineering enterprise: an educational perspective", European Journal of Engineering Education, Vol. 44 No. 4, pp. 461-483.

Vargo, S.L. and Lusch, R.F. (2004), "Evolving to a new dominant logic for marketing", Journal of Marketing, Vol. 68 No. 1, pp. 1-17.

Vargo, S.L. and Lusch, R.F. (2008), "Service-dominant logic: continuing the evolution”, Journal of the Academy of Marketing Science, Vol. 36 No. 1, pp. 1-10.

Vargo, S.L. and Lusch, R.F. (2017), "Service-dominant logic 2025”, International Journal of Research in Marketing, Vol. 34 No. 1, pp. 46-67.

Vargo, S.L., Akaka, M.A. and Vaughan, C.M. (2017), “Conceptualizing value: a service-ecosystem view”, Journal of Creating Value, Vol. 3 No. 2, pp. 1-8.

Vargo, S.L., Koskela-Huotari, K., and Vink, J. (2020), "Service-dominant logic: foundations and applications", in Bridges, E. and Fowler, K. (Eds), The Routledge Handbook of Service Research Insights and Ideas, Routledge, London and New York, NY, pp. 5-23.

Vargo, S.L., Maglio, P.P. and Akaka, M.A. (2008), "On value and value co-creation: a service systems and service logic perspective”, European Management Journal, Vol. 26 No. 3, pp. 145-152.

Vatin, F. (2013), "Valuation as evaluating and valorizing”, Valuation Studies, Vol. 1 No. 1, pp. 31-50.

Webster, F.E. and Lusch, R.F. (2013), "Elevating marketing: marketing is dead! Long live marketing!", Journal of the Academy of Marketing Science, Vol. 41 No. 4, pp. 389-399.

Yockey, J.W. (2014), "The compliance case for social enterprise", Michigan Business and Entrepreneurial Law Review, Vol. 4 No. 1, pp. 1-46.

Young, R. (2006), "For what it is worth: social value and the future of social entrepreneurship", in Nicholls, A. (Ed.), Social Entrepreneurship: New Models of Sustainable Social Change, Oxford University Press, Oxford and New York, NY, pp. 56-73.

Zahra, S.A. and Wright, M. (2016), "Understanding the social role of entrepreneurship”, Journal of Management Studies, Vol. 53 No. 4, pp. 610-629.

\section{Corresponding author}

Michaela Haase can be contacted at: michaela.haase@fu-berlin.de

For instructions on how to order reprints of this article, please visit our website:

www.emeraldgrouppublishing.com/licensing/reprints.htm

Or contact us for further details: permissions@emeraldinsight.com 